\title{
Effect of plant protection products on Rhynchophorus palmarum L. (Coleoptera: Curculionidae) larvae in laboratory*
}

\author{
Efeito de defensivos agrícolas sobre larvas de Rhynchophorus palmarum $L$. \\ (Coleoptera: Curculionidae) em laboratório
}

\author{
Samara dos Santos ${ }^{1}$, Valdemir Albuquerque da Silva Júnior ${ }^{1}$, Sonia Maria Forti Broglio', \\ Aldomario Santo Negrisoli Junior ${ }^{2}$ (D), Elio Cesar Guzzo ${ }^{1,2 * *}$ (D)
}

\begin{abstract}
With the aim of developing tools for simultaneously managing Rhynchophorus palmarum and the coconut stem bleeding disease, we evaluated the effects of the insecticide thiamethoxam and the fungicide cyproconazole on $R$. palmarum larvae under laboratory conditions. Early-instar and intermediate-instar larvae were fed on an artificial diet containing $0.1 \%$ concentration of insecticide, fungicide or a mixture of both. Larval mortality was assessed daily during the 48 hours after the application of the treatments. Mean mortality values were subjected to analysis of variance and compared by Tukey's test $(\mathrm{p} \leq 0.05)$. Thiamethoxam caused mortality of $100 \%$ of early-instar and $90 \%$ of intermediateinstar larvae. In contrast, mortality was significantly lower in the cyproconazole treatment $(60 \%$ for early-instar and $0 \%$ for intermediate-instar larvae) and the control (0\% mortality for both treatments). The insecticide/fungicide mixture was equally effective (100\% for early-instar and $86.67 \%$ for intermediate-instar larvae) to the insecticide only treatment. Differences in mortality between early-instar and intermediate-instar larvae were significant only for the thiamethoxam and cyproconazole treatments. These results indicate that, for the doses used here, thiamethoxam is toxic to both early-instar and intermediate-instar larvae, while cyproconazole is toxic just to early-instar larvae. Moreover, cyproconazole does not increase the toxicity of thiamethoxam. Early-instar larvae are more sensitive to thiamethoxam and cyproconazole than intermediateinstar larvae. We conclude that thiamethoxam + cyproconazole mixture may be effective for managing $R$. palmarum and associated fungal diseases on coconut palms.
\end{abstract}

KEYWORDS: Cocos nucifera; South American palm weevil; chemical control; thiamethoxam; cyproconazole.
RESUMO: Com o objetivo de desenvolver ferramentas para o manejo simultâneo de Rhynchophorus palmarum e da resinose do coqueiro, avaliou-se o efeito do inseticida tiametoxam e do fungicida ciproconazol sobre larvas de $R$. palmarum em laboratório. Larvas de ínstares iniciais e intermediários foram alimentadas com dieta artificial contendo $0,1 \%$ do inseticida, do fungicida, ou da mistura de ambos. A mortalidade larval foi avaliada diariamente, durante 48 horas, e as médias foram submetidas à análise de variância e comparadas entre si pelo teste de Tukey ( $\mathrm{p}$ $\leq 0,05)$. O tiametoxam causou mortalidade de $100 \%$ às larvas de ínstares iniciais e de $90 \%$ às de intermediários. Em contraste, a mortalidade foi significativamente menor no tratamento ciproconazol (60\% para larvas de ínstares iniciais e $0 \%$ para as de intermediários) e no controle ( $0 \%$ de mortalidade para ambos). A mistura inseticida/fungicida foi igualmente eficiente (100\% para larvas de ínstares iniciais e $86,67 \%$ para as de intermediários) ao inseticida sozinho. Diferenças na mortalidade entre as larvas de ínstares iniciais e intermediários foram significativas somente para os tratamentos tiametoxam e ciproconazol. Tais resultados indicam que, nas doses avaliadas, o tiametoxam é tóxico às larvas de ínstares iniciais e intermediários, enquanto o ciproconazol é tóxico somente às de ínstares iniciais. Além disso, o ciproconazol não aumenta a toxicidade do tiametoxam. Larvas de ínstares iniciais são mais sensíveis a tiametoxam e ciproconazol que as de ínstares intermediários. Conclui-se que a mistura tiametoxam + ciproconazol pode ser eficiente no manejo de $R$. palmarum e de doenças fúngicas associadas a essa praga em coqueiros.

PALAVRAS-CHAVE: Cocos nucifera; broca-do-olho-do-coqueiro; controle químico; tiametoxam; ciproconazol. 
Originally from the Pacific and Indian Ocean basins (GUNN et al., 2011), the coconut palm Cocos nucifera L. (Arecaceae) is nowadays one of the most geographically widespread cultivated species and has fundamental importance for the economy of several countries (MARTINS; JESUS JÚNIOR, 2011). In common with many widely cultivated species, the coconut palm is particularly prone to plant diseases and pest insects.

In Brazil, one of the main pests is the South American palm weevil Rhynchophorus palmarum L., 1764 (Coleoptera: Curculionidae). The weevil opens galleries in the apical region of the stem, which can cause the plant to die, and is also the vector of the nematode Bursaphelenchus cocophilus (Cobb) Baujard, which causes red ring disease of palms. Another disease that might be associated with the weevil is coconut stem bleeding caused by the fungus Thielaviopsis paradoxa (De Seyn), which was first recorded in Brazil in 2004 (WARWICK; PASSOS, 2009). Colonies of T. paradoxa have been successfully cultivated from the digestive tract of $R$. palmarum (PARRA et al., 2003), strongly suggesting that the weevil could play a role in the transmission of this disease.

At the present time, there are limited strategies available to control $R$. palmarum. The most commonly used of them are traps baited with the pheromone rhynchophorol to capture adult weevils. In contrast, there are no efficient control methods currently utilized in Brazil for red ring or stem bleeding diseases (AGROFIT, 2017) and infected trees need to be destroyed. Given the association of these diseases with $R$. palmarum, the best solution would be to simultaneously treat the pest and the diseases. Moreover, there are commercially available products that may be appropriate for this purpose. Specifically, the insecticide thiamethoxam is registered for use on several crops in Brazil and can be directly applied to leaves, trunks, seeds, seed furrows, or even used for seedling immersion, depending on the crop and the target pest. Most importantly, it is commercially available in several formulations in association with the fungicide cyproconazole (AGROFIT, 2017), which has been shown to reduce the symptoms of stem bleeding in coconut palms. Since thiamethoxam has systemic action, it may also be effective in the control of borer insects, such as $R$. palmarum. Furthermore, the availability of formulations with cyproconazole makes it a good candidate for the joint management of the pest and stem bleeding in coconut orchards.

Then, the objective of this work was to evaluate the effect of thiamethoxam, cyproconazole, and thiamethoxam + cyproconazole treatments on $R$. palmarum larvae in the laboratory.

Adults of $R$. palmarum were caught from a coconut plantation in the municipality of Feliz Deserto, on the south coast of Alagoas state, northeast Brazil (10 $15^{\prime} 53.919^{\prime \prime}$ $S$ and $\left.36^{\circ} 16^{\prime} 15.205^{\prime \prime} \mathrm{W}\right)$, using traps baited with the pheromone rhynchophorol (Interacta Química, Maceió, AL, Brazil) and sugarcane. Captured insects were taken to the laboratory, where they were separated into pairs and placed in plastic containers $(15 \times 10 \times 5 \mathrm{~cm})$. Each container was provisioned with pieces of coconut mesocarp, which served as an oviposition substrate. Eggs were collected daily and placed in Petri dishes (90 $\mathrm{mm}$ diameter) on moist filter paper. All laboratory procedures were carried out at $25 \pm$ $1{ }^{\circ} \mathrm{C}$, relative humidity (RH) of $60 \pm 10 \%$ and a 12 -hour photophase.

For the toxicity bioassays, an artificial diet (Table 1) modified from NEGRISOLI JUNIOR et al. (2011) was used. Initially, sugarcane fiber was obtained by grinding the peeled stalk in a blender with $100 \mathrm{~mL}$ of distilled water, placed in a pan along with the other ingredients (except for agar and propionic acid), and brought close to boiling point (approximately $96^{\circ} \mathrm{C}$ ), mixing until a homogeneous mass was obtained. The agar, previously dissolved in $100 \mathrm{~mL}$ of distilled water, was then added to the mixture, which was again homogenized and removed from the heat. Propionic acid was added when the solution reached around $45^{\circ} \mathrm{C}$. The solution was homogenized again and, after cooling and having acquired a pasty consistency, it was placed in a container with a lid and kept in a refrigerator $\left(12^{\circ} \mathrm{C}\right)$ for a maximum of one week.

Newly-hatched $R$. palmarum larvae were individualized in Eppendorf-type microtubes $(1.5 \mathrm{~mL})$ containing the artificial diet, which was replaced every two days, until they reached the size to be used in the bioassays. In order to get a better standard for bioassays, larvae were divided into two groups according to their size: early-instar larvae, approximately $1 \mathrm{~cm}$ in length; and intermediate-instar larvae, approximately $4 \mathrm{~cm}$ in length.

The insecticide thiamethoxam (Actara $250 \mathrm{WG}$ ) and the fungicide cyproconazole (Alto 100) were used in the treatments. The products were diluted in $500 \mathrm{~mL}$ of distilled water at the concentration of $0.1 \%(1,000 \mathrm{ppm})$.

Table 1. Composition of the artificial diet used in bioassays (modified from NEGRISOLI JUNIOR et al., 2011).

\begin{tabular}{lc} 
Ingredients & Quantity \\
\hline Propionic acid' & $0.75 \mathrm{~mL}$ \\
\hline Refined sugar & $11 \mathrm{~g}$ \\
\hline Agar' & $20 \mathrm{~g}$ \\
\hline Distilled water & $200 \mathrm{~mL}$ \\
\hline Wheat germ & $34 \mathrm{~g}$ \\
\hline Corn flour & $65 \mathrm{~g}$ \\
\hline Sugarcane fiber & $52 \mathrm{~g}$ \\
\hline Coconut oil & $2 \mathrm{~mL}$ \\
\hline
\end{tabular}

'Ingredients added after the diet cool. 
In tissue culture plates $(24$ cells), each cell received the artificial diet $(0.5 \mathrm{~g}$ for early-instar larvae and $10.0 \mathrm{~g}$ for intermediate-instar ones) with $0.5 \mathrm{~mL}$ of one of the three treatments applied $(0.25 \mathrm{~mL}$ of each product in the case of the mixture). After the solution was absorbed, one larva was placed on it and mortality was evaluated after 48 hours. Distilled water was used as a control. Four treatments (insecticide, fungicide, insecticide + fungicide, and control) were considered, with five replicates (= a set of six larvae). Mortality data were submitted to the Shapiro-Wilk normality test $(\mathrm{p}>0.05)$ and then to analysis of variance. Data that did not present normal distribution $(\mathrm{p}<0.05)$ were transformed to the arcsine of $\sqrt{x} / 100$. When normalized, they were analyzed through analysis of variance, and means were compared by Tukey's test at 5\% significance, using software GENES (CRUZ, 2013; 2016).

There was a statistically significant difference between treatments in relation to mortality of $R$. palmarum larvae in both size categories (Table 2). For early-instar larvae, both the thiamethoxam treatment and the mixture with cyproconazole caused $100 \%$ mortality, the cyproconazole treatment caused $60 \%$ mortality and there was no mortality in the control. These results indicate that cyproconazole is toxic to early-instar larvae of $R$. palmarum, though less so than the insecticide thiamethoxam. Intermediate-instar larvae also suffered high mortality in the thiamethoxam treatment $(90 \%)$ and the mixture $(86.67 \%)$. These results were significantly higher than the cyproconazole treatment and the control, which both caused zero mortality.

Thiamethoxam is toxic to several other curculionid pests of fruits (AFONSO et al., 2005; GUEDES et al., 2007; ŁABANOWSKA, 2009; LOUW et al., 2009; NÖRNBERG et al., 2016). However, there are no studies testing the efficacy of this product to control R. palmarum in coconut palms, limiting comparisons with the current study.

Early-instar larvae were more sensitive than intermediate-instar larvae in both the thiamethoxam and cyproconazole treatments, although no differences were observed for the other treatments (Table 2). The toxicity of a product to a given organism is a function of units of the toxicant per unit of body weight, with larger doses needed to kill a larger organism. Thus, it would be expected that smaller larvae are more susceptible to the insecticide than larger conspecifics. CABELLO et al. (1997) evaluated the mortality of Rhynchophorus ferrugineus Olivier, 1790 (Coleoptera: Curculionidae) larvae fed on a semi-artificial diet containing imidacloprid (another neonicotinoid insecticide) (0.1 $\mathrm{g}$ of a.i. $\mathrm{L}^{-1}$ ), obtaining $100 \%$ mortality for 7 - and 30 -dayold larvae after eight and five days of insecticide exposure, respectively. In the present study, mortality was evaluated only after two days of exposure, and it was therefore possible that intermediate-instar larvae would eventually reach $100 \%$ mortality given a prolonged period of exposure.

The low observed toxicity of cyproconazole to $R$. palmarum larvae can be explained by its mode of action. Cyproconazole is an ergosterol inhibiting fungicide that acts on the cytoplasmatic membrane, which contains this sterol. Insects, in contrast, have cholesterol instead of ergosterol and therefore do not depend on this sterol. Mortality in the early-instar larvae was probably due to their high sensitivity at this stage of life.

One factor that could limit the use of thiamethoxam in the field is its high toxicity to pollinators and other nontarget insects (PISA et al., 2015). However, DEMBILIO et al. (2015) found that the injection of imidacloprid in Phoenix canariensis Hort. ex Chabaud (Arecaceae) stem resulted in better distribution and greater persistence against $R$. ferrugineus when compared to frond injection and crown spraying. Such results suggest that the application of thiamethoxam in coconut palms via injection into the stem may also be efficient to control $R$. palmarum, while also reducing the undesired effects of topical exposure on non-target organisms. SANCHEZ-BAYO; GOKA (2014) have demonstrated that ergosterol inhibiting fungicides amplify toxicity of cyano-containing neonicotinoids. However, thiamethoxam belongs to the nitro-containing neonicotinoids, which are naturally more toxic than the

Table 2. Percent mortality (mean \pm SE) of early-instar and intermediate-instar larvae of Rhynchophorus palmarum, after 48 hours on an artificial diet containing thiamethoxam and cyproconazole.

\begin{tabular}{lcc} 
Treatments & Early-instar larvae & Intermediate-instar larvae \\
\hline Thiamethoxam & $100.00 \pm 0 \mathrm{aA}$ & $90.00 \pm 4.1 \mathrm{aB}$ \\
\hline Thiamethoxam + Cyproconazole & $100.00 \pm 0 \mathrm{aA}$ & $86.67 \pm 6.2 \mathrm{aA}$ \\
\hline Cyproconazole & $60.00 \pm 11.3 \mathrm{bA}$ & $0.00 \pm 0 \mathrm{bB}$ \\
\hline Control & $0.00 \pm 0 \mathrm{cA}$ & $0.00 \pm 0 \mathrm{bA}$ \\
\hline C. V. (\%) & 19.44 & 18.87 \\
\hline L. S. D. & 22.89 & 15.09 \\
\hline
\end{tabular}

SE: standard error; means followed by the same lowercase letter in the column and upper case in the row do not differ by Tukey's test ( $p \leq 0.05)$; C. V.: coefficient of variation; L. S. D.: least significant difference. 
other group (PISA et al., 2015), though do not show synergistic interactions with fungicides.

Studies in field condition still need to be carried out in order to validate our laboratory findings. However, based on the results obtained here, we conclude that endotherapy of coconut palms with a thiamethoxam + cyproconazole treatment is promising as a simple and effective strategy for the management of $R$. palmarum and associated fungal diseases.

\section{ACKNOWLEDGEMENTS}

To Coordenação de Aperfeiçoamento de Pessoal de Nivel Superior (CAPES), for granting the first author; and to Antonio de Sousa Vieira, M.Sc. André F. C. Amaral, and Dr. João Gomes da Costa, from Embrapa Tabuleiros Costeiros, for supporting insect collections, for assisting in bioassays, and for assisting with statistical analysis, respectively.

| | | | | | | | | | | | | | | | | | | | | | | | | | | | | | | | | | | | | | | | | | | | | | | | | | | | | | | | | | | | | | | | | | | | | | | | | | | | | | | | | | | | | | | | | | | | | | | | | | | | | | | | | | | | | | | | | | | | | | | | | | | | | | | | | | | | | | | | | | | | | | | | | | | | | | | | | | | | | | | | | | | | | | | | | | | | | | | | | | | | | | | | | | | | | | | | | | | | | | | | | | | | | | | | | REFERENCES

AFONSO, A.P.S.; FARIA, J.L.; BOTTON, M.; LOECK, A.E. Controle de Sitophilus zeamais Mots., 1855 (Coleoptera: Curculionidae) com inseticidas empregados em frutíferas temperadas. Ciência Rural, v.35, n.2, p.253-258, 2005.

AGROFIT: Sistema de Agrotóxicos Fitossanitários. Ministério da Agricultura, Pecuária e Abastecimento, 2017. Available from: <http://extranet.agricultura.gov.br/agrofit_cons/principal_ agrofit_cons>. Accessed on: Jan. 112017.

CABELLO, T.; PEÑA, J.; BARRANCO, P.; BELDA, J. Laboratory evaluation of imidacloprid and oxamyl against Rhynchophorus ferrugineus, new pest of palms in Spain. Annals of Applied Biology, v.130, p.6-7, 1997.

CRUZ, C.D. GENES - a software package for analysis in experimental statistics and quantitative genetics. Acta Scientiarum. Agronomy, v.35, n.3, p.271-276, 2013.

Genes Software-extended and integrated with the R, Matlab and Selegen. Acta Scientiarum. Agronomy, v.38, n.4, p.547-552, 2016.

DEMBILIO, O.; RIBA, J.M.; GAMÓN, M.; JACAS, J.A. Mobility and efficacy of abamectin and imidacloprid against Rhynchophorus ferrugineus in Phoenix canariensis by different application methods. Pest Management Science, v.71, p.1091-1098, 2015.

GUEDES, J.V.C.; FARIAS, J.R.; ROGGIA, S.; SULZBACH, F. Eficiência de inseticidas no controle de larvas e adultos de curculionídeosdas-raízes em citros. Pesquisa Agropecuária Tropical, v.37, n.2, p.65-70, 2007.

GUNN, B.F.; BAUDOUIN, L.; OLSEN, K.M. Independent origins of cultivated coconut (Cocos nucifera L.) in the Old World tropics. PLOS ONE, v.6, e21143, 2011.

$Ł A B A N O W S K A, B . H$. The efficacy of some neonicotinoid and other new insecticides in the control of the strawberry root weevils (Cucurlionidae) on strawberry plantations in Poland. Journal of Fruit and Ornamental Plant Research, v.17, n.2, p.211-218, 2009.

LOUW, C.E.; LE LAGADEC, M.D.; LABUSCHAGNE, C.L.; ERASMUS, A.A. Efficacy of Actara ${ }^{\text {TM }}$ 240SC (thiamethoxam), applied as a drench against mango seed weevil (Sternochetus mangiferae) on mangoes in South Africa. Acta Horticulturae, v.820, p.559566, 2009.

MARTINS, C.R.; JESUS JÚNIOR, L.A. A evolução da produção de coco no Brasil e o comércio internacional. Aracaju: Embrapa Tabuleiros Costeiros, 2011 . 28p. (Embrapa Tabuleiros Costeiros, Documentos, 164). Available from: <http:// www.cpatc.embrapa.br/publicacoes_2011/doc_164.pdf $>$. Accessed on: Jan. 122017.

NEGRISOLI JUNIOR, A.S.; SILVA, E.S.; BARBOSA-NEGRISOLI, C.R.; SANTOS, N.L.; GUZZO, E.C. Criação em laboratório da brocado-olho-do-coqueiro Rhynchophorus palmarum L. (Coleoptera: Curculionidae) visando pesquisas para o controle das suas larvas. Aracaju, Embrapa Tabuleiros Costeiros, 2011, 6p. (Embrapa Tabuleiros Costeiros, Comunicado Técnico, 116). Available from: <http://www.cpatc.embrapa.br/publicacoes_2011/cot_116. pdf >. Accessed on: Jan. 122017.

NÖRNBERG, S.D.; GRÜTZMACHER, A.D.; NAVA, D.E.; VALGAS, R.A.; OZELAME, A.L. Residual effects of pesticides in peach orchards on the maize weevil Sitophilus zeamais (Coleoptera: Curculionidae). Revista Brasileira de Fruticultura, v.38, e-017, 2016.

PARRA, D.; MORILLO, F.; SÁNCHEZ, P.; PINEDA, J.; GUERRA, J. Presencia de Thielaviopsis paradoxa De Seynes Höhn en el tubo digestivo de Rhynchophorus palmarum Linneo (Coleoptera: Curculionidae). Entomotropica, v.18, n. 1, p.49-55, 2003.

PISA, L.W.; AMARAL-ROGERS, V.; BELZUNCES, L.P.; BONMATIN, J.M.; DOWNS, C.A.; GOULSON, D.; KREUTZWEISER, D.P.; KRUPKE, C.; LIESS, M.; MCFIELD, M.; MORRISSEY, C.A.; NOOME, D.A.; SETTELE, J.; SIMON-DELSO, N.; STARK, J.D.; VAN DER SLUIJS, J.P.; VAN DYCK, H.; WIEMERS, M. Effects of neonicotinoids and fipronil on non-target invertebrates. Environmental Science and Pollution Research, v.22, p.68-102, 2015.

SANCHEZ-BAYO, F.; GOKA, K. Pesticide residues and bees - a risk assessment. PLOS ONE, v.9, e94482, 2014.

WARWICK, D.R.N.; PASSOS, E.E.M. Outbreak of stem bleeding in coconuts caused by Thielaviopsis paradoxa in Sergipe, Brazil. Tropical Plant Pathology, v.34, n.3, p. 175-177, 2009. 